УДК 159.9:316.6

doi: $10.15330 /$ ps.10.1.99-110

\title{
Олена Галян
}

Дрогобицький державний педагогічний університет імені Івана Франка halyane@ukr.net

\section{Ігор Галян}

Дрогобицький державний педагогічний університет імені Івана Франка halyan@ukr.net

\section{ОСОБА 3 ІНВАЛІДНІСТЮ У РЕФЛЕКСІЯХ СТУ ДЕНТІВ-ПСИХОЛОГІВ}

\begin{abstract}
У статті проаналізовано теоретико-прикладні аспекти формування у студентської молоді когнітивного, емотивного та конативного компонентів ставлення до осіб з інвалідністю (інвалідизованих). Ставлення в міжособистісному пізнанні відображають той аспект взаємодії, який стосується зіставлення об 'єктивного світу та його суб'єктивної інтерпретаиії. Зміст психологічного ставлення формується під впливом соціальних настановлень, уявлень та індивідуального досвіду взаємодії з різними категоріями осіб. Засвідчено домінування соиіальної моделі сприймання інвалідизованого, в якій провідна роль належсть пошуку його місия в сочіумі, визначення иляхів самореалізачії та оптимального жситтєздійснення. Доведено, шьо в сучасних умовах спостерігається тенденція до заміни побутових стереотипів сприймання інвалідизованих професійними уявленнями, завдяки яким окреслюються підходи до формування в суспільстві толерантного ставлення до иієї групи осіб. Диференційовано вплив соціального та особистісного контексту толерантності студентів на ставлення до осіб з обмеженими можливостями. Конкретизовано фактори, які визначають сприймання інвалідів та ставлення оточення до них. Акцентування на особистісних, вольових та соціально-психологічних проявах осіб з обмеженими можливостями постало детермінантами формування системи ставлень до них. Водночас визнано наявність індивідуальних варіантів психічної активності осіб з інвалідністю, а відповідно й ієрархії їхніх провідних рис. Обгрунтовано потребу удосконалення психолого-педагогічного супроводу особистісного розвитку студентів в умовах закладу вищої освіти, де підтримується прагнення усіх суб'єктів освітнього процесу до продуктивного самоздійснення.
\end{abstract}

Ключова слова: психологічне ставлення, компоненти ставлення, моделі сприймання осіб з інвалідністю, інвалідизована особа, психологічний портрет івалідизованого, толерантність, самореалізація.

Постановка проблеми. Сучасні умови життєздійснення орієнтовані на толерантне ставлення до наслідків глобалізації, які, безумовно, можна вважати чинником невротизації особистості. Так відбувається тоді, коли в людини несформовані адекватні настановлення на різновекторність, мозаїчність змін суспільного буття. Успішній самореалізації сприяє зміна схем миследіяльності, завдяки яким в особистості формується спрямованість та мотивація на досягнення на відміну від мотивації на уникнення невдачі. У контексті означеного особливо актуалізуються питання ставлення, в яких закладено бачення шляхів співіснування в просторі та часі взаємодії з оточенням. Акцентуємо, що, соціалізуючись, особистість набуває не тільки визначених рис та характерних проявів, але і здатності виражати власне ставлення до різних сторін життя, людей, суспільних викликів. Водночас система ставлень зазнає змін, опосередко-вуючись культурно й соціально, як результат суспільство через свої інститути транслює особистості оновлене знання про моделі суспільного співбуття, можливості самоздійснення незалежно, наприклад, від стану здоров'я, сприймання Іншого здатним виконувати конкретні завдання.

Засадничим для стосунків суспільства та осіб з інвалідністю $є$ поняття «соціальна незалежність». Ї̈̈ сутність пов'язана не тільки з адаптацією або компенсацією соціальних проблем цієї групи людей, а насамперед з творчим, активним подоланням, досягненням максимально можливої самоактуалізації та самореалізації інвалідизованих. У зв'язку 3 цим варто акцентувати, що інвалідність $є$ проблемою не тільки людини з обмеженими можливостями, це актуальне питання суспільства загалом. Тому вивчення особливостей ставлення до інвалідів, наявних у цьому процесі бар'єрів сприятиме їх усуненню на основі 
науково обгрунтованого підходу. У ньому соціальний аспект стає визначальним під час аналізу тих проблем, які турбують людей.

Аналіз останніх досліджень і публікацій. Традиційно ставлення до осіб з інвалідністю зумовлювалося суспільними догмами та ідеологемами, які панували в ту чи іншу історичну епоху. Як зазначають дослідники цієї проблеми (М. Аравіцька, І. Петрів [1]; О. Богучарова [3]; Т. Добровольська, Н. Шабаліна [5]; Л. Мазай [11]), ситуація ізолювання та негативу щодо інвалідів зазнала змін у 50-60 роках XX століття спочатку на рівні державної підтримки (правова, медична, економічна, педагогічна тощо), а згодом і соціальнопсихологічної. Стратегічно ж питання самореалізації інвалідів до цього часу є гостро дискусійними, адже потребують як теоретичного обгрунтування, так і розроблення прикладного аспекту реалізації на рівні різних соціальних інституцій, а не тільки правового забезпечення (що, безперечно, є важливим [4]) та інклюзивної освіти [12].

В умовах запровадження принципу толерантності особи з інвалідністю стали об'єктом уваги дослідників, а ставлення до них спеціальним предметом вивчення соціологів (Л. Пірог [13]), педагогів (А. Колупаєва [9]), психологів та представників інших галузей людинознавства [10]. Констатуємо, що вивчалися в основному такі феномени: концепції розуміння інвалідності, місце навчання дітей з інвалідністю, загального сприйняття в українському суспільстві дітей та молоді з інвалідністю, соціально-психологічні аспекти цього аспекту ставлення, виховання толерантного сприймання осіб з обмеженими можливостями та інвалідів, профілактики гандикапізма (ставлення до особистості «людейінших» (О. Ставицький $[15 ; 16])$ тощо. Попри те, що в сучасному суспільстві підтримується ідея рівних можливостей для самовираження та самореалізації будь-якої категорії осіб, надання шансів кожному для розвитку та оптимального функціонування, проблема ставлення до інвалідизованих залишається актуальною.

Метою статті $є$ представлення результатів теоретико-емпіричного пошуку в царині психологічних особливостей ставлення сучасної студентської молоді до інвалідизованих. Ïї досягнення спонукало до окреслення чинників формування психологічного ставлення до осіб з особливими потребами, вияву традиційних та сучасних поглядів на можливості їхнього життєздійснення; розкриття провідних тенденцій сформованого ставлення студентів-психологів до інвалідизованих; систематизації особистісних проявів осіб 3 інвалідністю в рефлексіях досліджуваних; виокремлення мети психологічної просвіти в системі вищої освіти щодо підтримки прагнення інвалідизованих до оптимальної самореалізації в навчальній та навчально-професійній діяльності.

Методи та методики. Вибір змісту психодіагностичної програми грунтувався на сучасних методологічних та методичних підходах. В їх основу покладено такі принципи: 1) отримувати матеріал зі зразків обговорення, яке зазвичай панує в суспільстві (теми, актуальні для сьогодення, зокрема в контексті сучасного обговорення проблем інклюзії); 2) розглядати соціальні уявлення як способи відтворення реальності (це не тільки уявна ситуація, але й реальність, яку відтворюємо в образах, водночас змінюючи образи, а відтак і ставлення до, у нашому випадку, інвалідизованих: усвідомлення породжує зміну ставлення); 3) характер соціальних уявлень найяскравіше виявляється в періоди змін (люди, які живуть в епоху змін, гостро відчувають потребу пізнання світу, який змінюються, у ситуації проживання поряд 3 інвалідизованими постає завдання осмислення нової реальності, усвідомлення актуальності жити, вчитися, працювати поряд з ними, а отже, віднайти способи оптимальної взаємодії; 4) носії ставлення повинні розглядатися за аналогією 3 «ученими-любителями» (використовувати неофіційну інформацію про інвалідизованих, результати спостереження, споглядання їх успіхів, прагнень уможливлює розкриття тих сторін їх особистості, які не приймалися або не вважалися актуальними); 5) врахування широкоформатної системи обговорення, яка стала можливою завдяки мережі Internet, мотиваційним тренінгам (Нік Вуйчіч); 6) врахування багатомірності досліджуваного феномену як складного явища. 
Насамперед досліджуваним пропонувалося відповісти на питання анкети. Ї̈ї зміст спрямовано на вивчення уявлень студентської молоді про ставлення суспільства до інвалідизованих, оцінювання власних емоційних реакцій на потребу контактування 3 ними, осмислення значущості толерантного ставлення до цієї групи осіб, водночас окреслення психологічного портрета людини з обмеженими можливостями. Запропонована інструкція скеровувала студентів до вільного висловлювання власної позиції, адже анкетування було анонімним. Взаємодоповнювальним стало використання «Шкали ставлення». Запропонована методика побудована за принципом семантичного диференціала. 3 іï допомогою вивчалися уявлення досліджуваних про себе, оцінювання ними якостей «ідеальної особи» та осмислення типових проявів рис особистості осіб з інвалідністю. 3 огляду на актуальність адекватного сприймання суспільством різних категорій осіб ми припустили, що воно прямо залежить від рівня толерантності особистості. Для підтвердження цього факту ми застосували експрес-опитувальник «Індекс толерантності» (Г. Солдатова, О. Кравцова, О. Хухлаєв, Л. Шайгерова). Стимульний матеріал склали твердження, які містили загальне ставлення до світу та оточення, соціальні настановлення.

Виклад основного матеріалу. Уразливість осіб з інвалідністю пов'язана, з одного боку, із їх самосприйманням, а $з$ іншого - ставленням суспільства, окресленням можливостей для самореалізації, які не задовольняють потребу інвалідизованих віднайти своє місце в соціумі. Звернемося до розлогої цитати, в якій чітко визначено пролемні моменти у сприйманні осіб з обмеженими можливостями: «Насамперед, діти з інвалідністю - хороші друзі, старанні учні, цілеспрямовані таланти, і лише потім йде їхня інвалідність. Якщо наше суспільство навчиться сприймати дітей з інвалідністю через таку призму, це вже буде перемогою кожного, хто воліє жити в рівноправному і справедливому світі» [14]. Вона належить Н. Скрипці - виконавчому директорові Національної Асамблеї інвалідів України, яка не тільки розуміє труднощі соціалізації осіб з інвалідністю, але й знає про психологічний контекст ставлення до них.

Індиферентність, а в окремих випадках і негативне сприймання соціумом осіб 3 інвалідністю детермінує їхнє неадекватне ставлення до самих себе, заниження самооцінки власних можливостей, комплекс меншовартості щодо самоздійснення. Таврування нездатності інвалідизованих бути рівноправними членами суспільства породжує в оточення прагнення надавати їм допомогу, опікуватися ними та доглядати їх, вирішувати за них нагальні проблеми поряд із недовірою до їхніх можливостей. Деклароване деформує та нівелює в осіб з обмеженими фізичними можливостями прагнення до самовдосконалення, нав'язуючи їм адаптивні моделі пристосування до умов життя. Отже, оточення, відображаючи стереотипні настановлення, здатне акцентувати на одних рисах інвалідизованих, попри наявність інших, зокрема, тих особистісних характеристик та здібностей, які сприяли б оптимізації середовища їхнього саморозвитку.

Ставлення у суспільстві до інвалідизованих пов'язуємо з дією низки чинників, які можуть бути розглянуті як окремо, так і в комплексі, виступати як фактори змін або як бар'єри на шляху до створення відповідного розвивального середовища для цієї групи осіб. Йдеться про конкретні культуральні особливості [17], важливі для структурування в соціумі уявлень про осіб з обмеженими можливостями та їх місця в суспільному житті. Адже загальновизнано вплив важливих компонентів соціуму на процес їхнього включення до адекватного товариства.

Зважаючи на наявність паралельного існування та взаємовпливу традиційної, медичної та соціальної моделі інвалідності [10], ми у своїй роботі спиралися саме на останню. У ній акцентовано на тому, що труднощі, які виникають в інвалідів, насамперед пов'язані з умовами їх існування в конкретному соціальному просторі. Повноцінне життя залежить від того, чи готове суспільство до інтеграції осіб з інвалідністю в соціальне середовище, конкретну спільноту, як воно сприймає людину з обмеженими можливостями, чи сприяє набуттю нею поряд із фізично «здоровими» людьми відповідних до віку навичок та повній реалізації потенційно закладеного. 
Погляд на роль середовища потрібно аналізувати на основі конкретизації знання про індивідуальний досвід щодо залучення інвалідів до життя в суспільстві. 3 огляду на те, що сучасні дорослі в умовах тоталітарного дитинства та ізоляції інвалідів не отримали такого досвіду, констатуємо, що їхнє ставлення до цієї групи осіб є доволі складним і неоднозначним. Водночас впродовж останніх років у суспільстві активно розвиваються ідеї інтеграції, інклюзії, нормалізації, що створює підгрунтя до засвоєння молоддю нових патернів взаємодії з інвалідами. Культура стосунків і контактування набуває вираженого толерування до інвалідизованих, а подекуди й прогресивності поглядів на їх виключність та лідерство з огляду на виявлені здібності у вирішенні пізнавальних і життєвих завдань. Отже, побутові погляди на інвалідність поступаються місцем професійним.

Однак означене не лише частково характерне для сучасного етапу життя осіб 3 інвалідністю. Те, що декларується, зазнає ситуативних впливів, і спонтанна поведінка оточення може відрізнятися від типової. Таким чином, суспільство теоретично готове i схвально ставиться до інвалідизованих під час опитувань різного рівня. Водночас реальний досвід зазвичай не вивчається. Тому зіставити знання («правильні декларації») та дії («правильні дії») щодо осіб з інвалідністю не представлені у науковому контексті.

«Суспільство загалом» щодо інвалідизованого є макросистемою, яка розглядається як носій наявних у ньому настановлень та норм, які транслюються на всі рівні системи життя такої особистості від ії екзо- до мікросистеми. Зазначмо, що досвід діяльного, адекватного ставлення може бути забезпечений лише в процесі активної взаємодії з інвалідизованим. Попри це такий досвід потребує зовнішнього керування, адже традиційне настановлення на сприймання особи з обмеженими можливостями як немічної формує неадекватні уявлення про ії здатність бути повносправним учасником суспільного буття, а тому не відповідає сучасним уявленням про зміст стосунків із нею.

Вітчизняна стратегія інклюзивної освіти забезпечує можливість отримання дітьми та молоддю такого досвіду й орієнтована на вироблення в системі психологічного супроводу адекватних моделей і підходів до залучення осіб з особливими освітніми потребами в соціум з одночасним формуванням в оточення відповідно позитивного ставлення до життєздійснення цих людей [12]. По суті, йдеться про створення інтегративного середовища, де набувається досвід успішної взаємодії, який потрібен і інвалідизованим, $\mathrm{i}$ їхнім «здоровим» ровесникам.

Особливого значення у зв'язку з цим набувають питання формування толерантного ставлення до осіб з інвалідністю та завдання профілактики гандикапізму. Як зазначив О. Асмолов, толерантність проявляється як мистецтво жити у світі несхожих людей та ідей [2], готовність приймати відмінності іншого (зокрема, й фізичні), його форми самовираження, індивідуальність його реакцій та поведінки. Толерантне ставлення до осіб 3 інвалідністю передбачає вияв активної моральної позиції та психологічної готовності діяти спільно, адекватно до ситуації, без упередження щодо здатностей партнера по спілкуванню бути повноцінним учасником взаємодії. Високий рівень толерантності серед молоді засвідчує визнання нею права інвалідів на інший образ життя, підвищену сприйнятливість до будь-яких проявів дискримінації, уникнення суспільних забобонів щодо осіб з обмеженими фізичними можливостями, здатність сприймати їх як носіїв позитивних якостей та цінностей, які можуть бути ідентифіковані як важливі [8].

В останні десятиліття активно обговорюються питання інтолерантного ставлення до цієї групи осіб, зокрема в контексті аналізу особливостей та детермінант виникнення гандикапізму [15] i, що особливо важливо, його профілактики (О. Ставицький та ін.). Деструктивні настановлення щодо осіб з інвалідністю зазвичай розглядалися у межах психологічного дизонтогенезу та різних нозологій порушень психічного розвитку, дефектів сенсорної, інтелектуальної, емоційної сфер. Як суспільне явище, реакцію гандикапізму характеризує несприйняття, негатив у ставленні до осіб з обмеженими можливостями [16]. Це своєю чергою сприяє руйнації стосунків, погіршенню систем взаємин, появі напру- 
женості. Відтак виникають труднощі вияву індивідуальних рис, підкреслення власної унікальності.

3 огляду на різні підходи до інтерпретації явища толерантності / інтолерантності його заведено аналізувати в контексті функціонування психозахисних механізмів та стратегій поведінки (психоаналітичний аспект), соціальної категоризації, когнітивного дисонансу, соціальних стереотипів та настановлень (когнітивна психологія), задоволення соціальних потреб, формування основ поведінки (біхевіоризм), ціннісно-орієнтованого та особистісно-смислового визначення (гуманістична психологія).

Завдання емпіричного етапу дослідження виходили з припущення про відсутність дискримінації та ізоляції у ставленні студентської молоді до інвалідизованих. Таке передбачення викликано особливостями обраної вибірки. Її склали здобувачі вищої освіти спеціальності 053 «Психологія» факультету психології, педагогіки та соціальної роботи Дрогобицького державного педагогічного університету імені Івана Франка. Усі вони ознайомлені в межах освітньої програми з особливостями осіб з інвалідністю. Крім того, інформовані, а окремі з них залучені як волонтери, практиканти до організації психологічної допомоги людям 3 обмеженими можливостями (Добровільне товариство «Надія», інклюзивно-ресурсний центр м. Дрогобича). Студентське товариство факультету активно підтримує майбутніх фахівців, які мають інвалідність і навчаються поряд. Таким чином, обрані нами досліджувані не тільки знають про колег з інвалідністю, мають змогу спостерігати за їхніми успіхами, прагненнями, але й взаємодіють з ними. Вибірка була гетерогенною. Однак значних відмінностей у досліджуваних феноменах хлопців і дівчат не виявлено, тому проаналізовані результати стосуються всієї вибірки загалом.

У контексті нашого дослідження об'єктом вивчення став когнітивно-емотивний аспект міжособистісної взаємодії, що характеризує уявлення про осіб з обмеженими можливостями та ставлення до них. Адже цим вимірюється гуманність суспільства, його інтегративні тенденції та виховний потенціал.

Проведене опитування уможливило визначення загальних особливостей досліджуваного феномену. Зокрема констатовано, що більшість студентів адекватно позитивно ставиться до осіб з інвалідністю (78,1\%). Лише 21,9\% висловили нейтрально-байдуже ставлення (рис. 1). Водночас 3'ясовано домінування співчуття та позитивних емоцій щодо інвалідизованих (68,8\%). Частина ж студентів (15,6\%) відчувають жалість та співчуття.

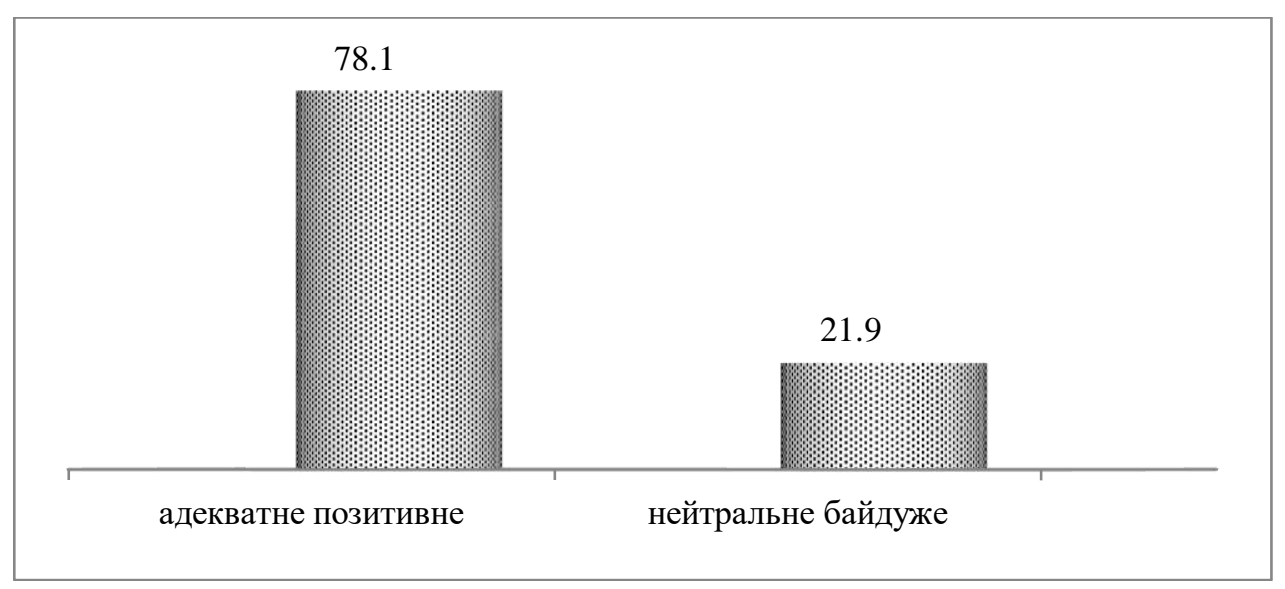

Puc. 1. Показники емоційного аспекту ставлення до осіб з інвалідністю

Той факт, що особи з інвалідністю навчаються в закладі вищої освіти, де проводилося дослідження, визначили відсутність особливих зауваг щодо їх перебування під час навчання поряд із «фізично здоровими» студентами. Досвід спільної діяльності дав змогу більш осмислено підійти до аналізу особистості тих, хто входить в групу осіб з обмеженими можливостями. 
Характеризуючи особистісні риси інвалідизованих, студенти акцентували на таких їхніх якостях, як доброзичливість, наполегливість, сила волі, цілеспрямованість, терпеливість. Однак вказували, що вияв особистісних особливостей залежить від індивідуальності інвалідизованого, а також соціального контексту його життя. Зустрічалися в їхньому житті особи, які виявляли демонстративність, бажання отримувати більше уваги, використовуючи для цього будь-які засоби (наприклад, нецензурна лайка). Означене потрібно розглядати як наслідок самосприймання особи з інвалідністю самої себе, тієї нозології, 3 якою вона живе, соціального оточення та його настановлення щодо інваліда (наприклад, неадекватні, негативні емоції батьків, однолітків тощо). Чітко простежується у відповідях респондентів думка про те, що особи з інвалідністю потребують толерантного оточення, розвивального середовища, адекватного ставлення без жалості для повноцінного самовиявлення ними своїх потенційних здатностей. Особи з обмеженими можливостями, залучені у сприятливі умови, стають частиною соціуму. Вони, якщо не йдеться про розумову патологію, є активними учасниками усіх процесів, які відбуваються в найближчому оточенні.

Однак з'ясовано, що позитивне ставлення здебільшого є уявлюваним. Тобто респонденти знають проблеми інвалідизованих. Водночас постійно та достатньо контактно 3 ними в одному часопросторі не перебувають. Тому висловимо припущення, що сформовані настановлення у студентів є позитивними, адекватними 3 урахуванням гуманітаризації освітнього середовища, а також вимог їхньої майбутньої діяльності. Тривалого досвіду контактування та супроводу різних сторін життєдіяльності осіб з інвалідністю вони не мають, а отже, оцінюють власні емоційно-поведінкові реакції з особистісно-професійних позицій. Цей факт вважаємо одним із чинників психологічної готовності студентської молоді до взаємодії з інвалідизованими.

Вивчення здатності респондентів виявляти толерантність у спілкуванні з різними категоріями осіб та у різних соціальних умовах засвідчило переважання середнього рівня прояву цього психологічного феномену (рис. 2), що вказує на усвідомлення ними значущості терпеливого ставлення до викликів соціуму, гуманістичного потенціалу особистості досліджуваних, їхню орієнтацію на врахування різного роду детермінант в інтерпретації поведінки оточення, аналізу їх життєвих сценаріїв та індивідуально своєрідних умов життєздійснення. Отримані результати засвідчили статистично значущу дисперсію за вибіркою загалом: низький - 18,8\%, середній $-59,4 \%$ та високий $-21,8 \%$.

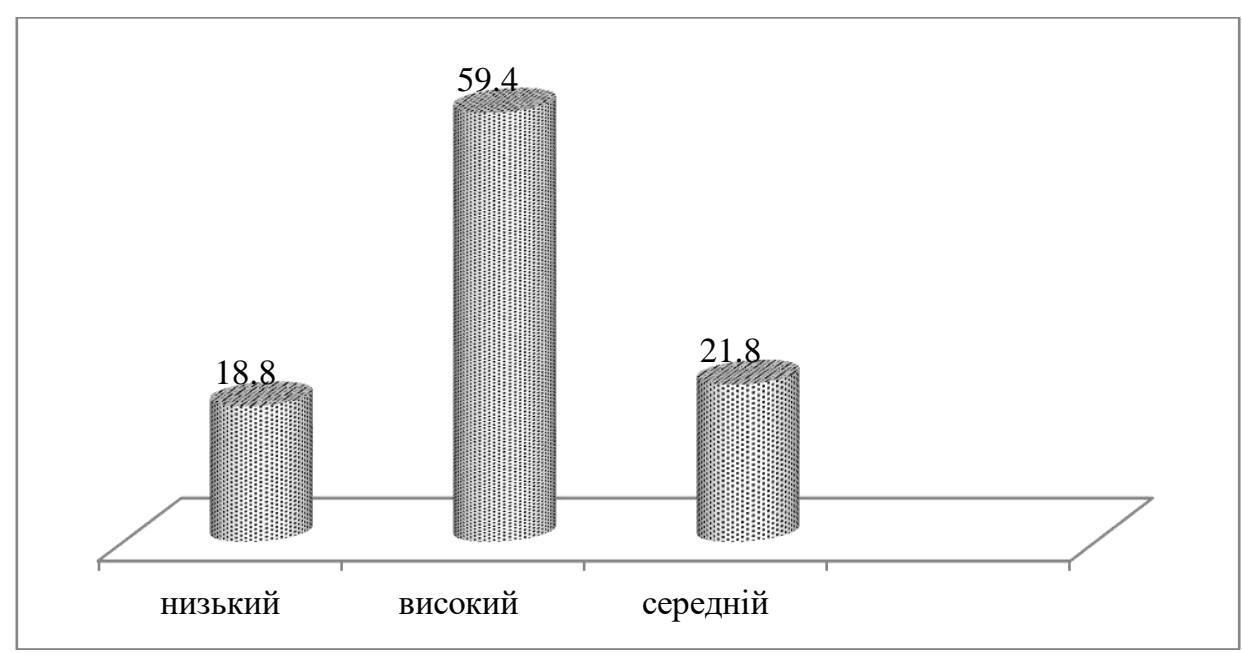

Рис. 2. Розподіл рівнів загального індексу толерантності студентів - майбутніх психологів

Диференціюємо показники індексу толерантності за субшкалами «Соціальна толерантність» та «Толерантність як риса особистості» (див. рис. 3). Як бачимо, показники толерантності як особистісної риси мають нижчий прояв, ніж іiі соціальна детермінація. 3 огляду на це можемо зробити висновок про актуальність зовнішньо орієнтованого спонукан- 
ня до вияву терпеливості студентською молоддю порівняно 3 внутрішньо зумовленим прагненням відповідати власному образу учасника спільної діяльності. Зовнішнє схвалення для студентів все ще залишається значущим. Формування толерантності як риси особистості визнаємо важливим напрямом роботи кураторів груп, студентського самоврядування та організованої системи психолого-педагогічного супроводу освітнього процесу, в якому застосовуються елементи інклюзивного навчання.

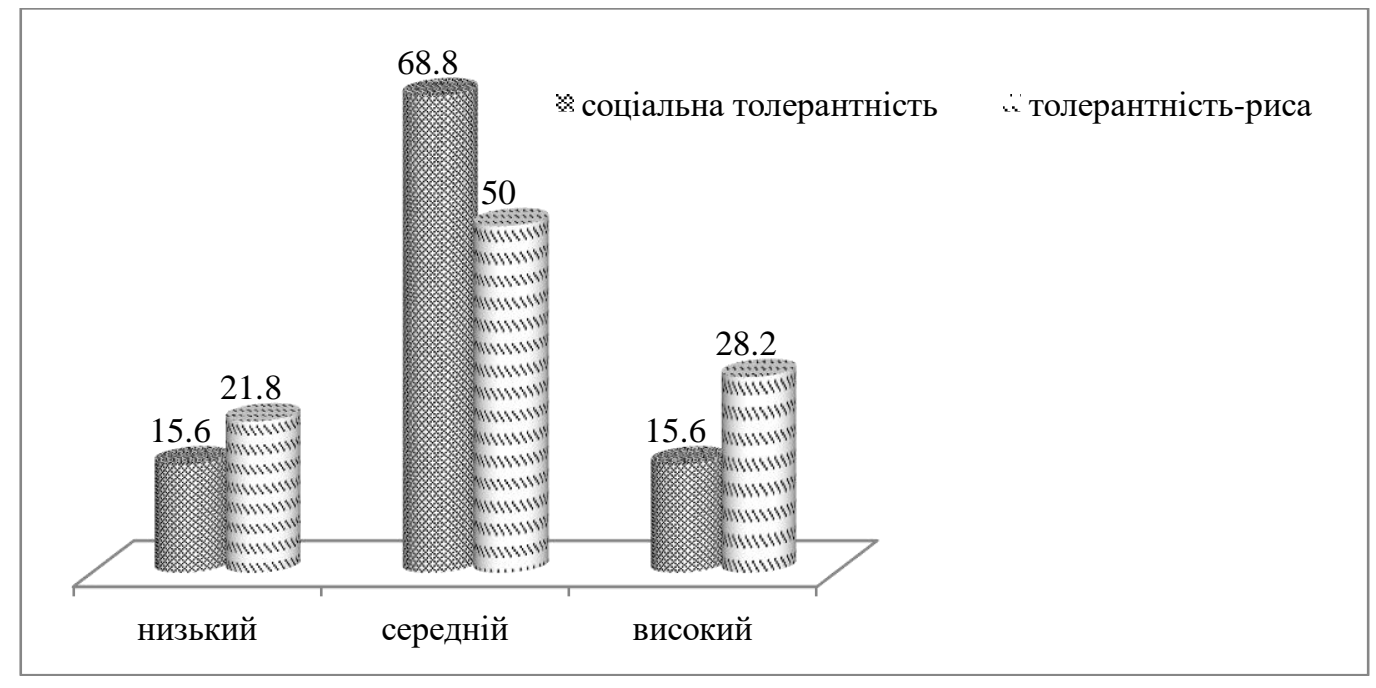

Рuc. 3. Розподіл показників соціальної толерантності та толерантності як риси особистості респондентів

Порівняння переважних емоційних реакцій і емоційного компонента ставлення та рівнів толерантності показало, що за адекватного позитивного ставлення рівень толерантності студентів є середнім з тенденцією до високого. Більшість із тих, хто виявив байдуже ставлення, має низький рівень толерантності.

Особливу увагу ми приділили результатам діагностики, отриманим за допомогою «Шкали ставлення». Важливо підкреслити, що в системі сформованих уявлень та відповідних їм ставлень провідну роль відіграють соціальні настановлення як результат панівної в суспільстві стереотипізації різних категорій осіб, зокрема й інвалідизованих. Традиційне уявлення спрощено презентує особистісні риси цієї групи людей. Йдеться про переважання у них заниженої самооцінки, недостатнього рівня амбіцій та пасивну соціальну адаптацію [6]. На нашу думку, вивчення особливостей ставлення молоді до осіб з інвалідністю сприяе зміні суспільної думки, заміні традиційних стереотипів інноваційними підходами.

Вивчення сприймання інвалідизованого сучасною студентською молоддю та ставлення до нього уможливило складання його психологічного портрета. Профіль особистісних якостей представлено на рис. 4. Констатуємо: стереотипні уявлення про особистісні характеристики осіб з інвалідністю зазнали змін. Молодь сприймає людей з обмеженими можливостями цілеспрямованими, чутливими, з почуттям гідності, доволі допитливими, посидючими, тактовними, деякою мірою впевненими, що виявляють пунктуальність, сміливість, люб'язність, здатність бути веселими. Водночас респонденти акцентують на стурбованості інвалідів ставленням оточення, що, своєю чергою, викликає боязливість, а породжений страх - апатію та небажання діяти. Стверджуємо, що у досліджуваних стосовно образу інвалідів домінує соціальна модель, в якій провідна роль належить пошуку місця інвалідизованого у соціумі, визначення шляхів його самореалізації та оптимального життєздійснення. 


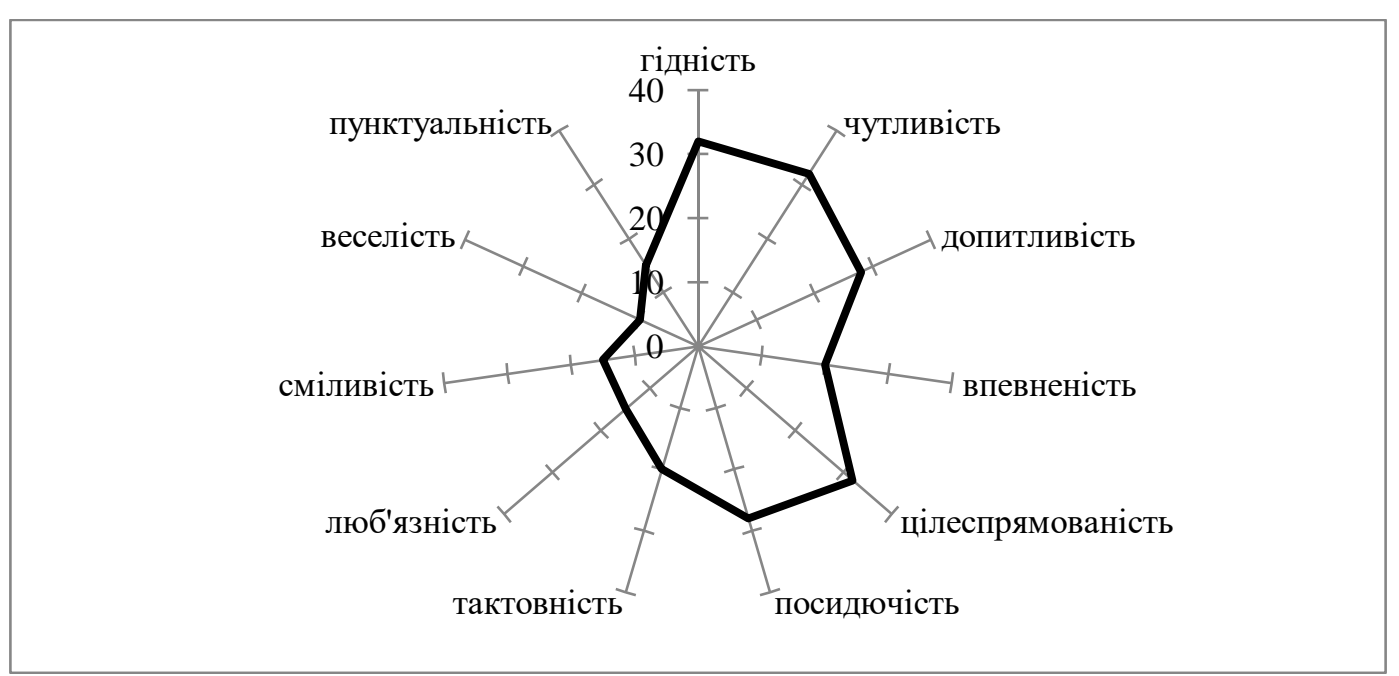

Рис. 4. Провідні риси осіб з інвалідністю у поглядах студентів - майбутніх психологів

Студенти характеризують осіб з інвалідністю в основному позитивно, без акцентування на дефектах, наголошуючи на характерологічних проявах та соціальній поведінці, водночас з урахуванням індивідуальної своєрідності та віднесеності конкретних якостей до конкретного носія, або його ідеального образу. Передбачаємо, що ставлення до особи 3 інвалідністю, окрім досвіду спілкування, суспільно-політичних детермінант та споглядання зумовлено видом дефекту, його видимістю. Отже, що менше зовні виявлена нозологія, то більше позитивних рис притаманно образу особи з інвалідністю; що більше видимих ознак інвалідності, то більше негативних якостей приписується образу ії життєздійснення.

У межах використаної методики було проаналізовано також оцінювання студентами себе та «ідеальної» особистості (рис. 5). Отримані дані засвідчили, що за всіма якостями самооцінка $\epsilon$ нижчою, ніж уявлення про риси «ідеальної» особистості. Цей факт дає змогу визнати їхню здатність до об'єктивності, а отже, адекватності репрезентації й образу інвалідизованого (рис. 4). Отже, вважаємо його наближеним до реальної ситуації сприймання таких осіб у всій складності їхніх індивідуальних проявів.

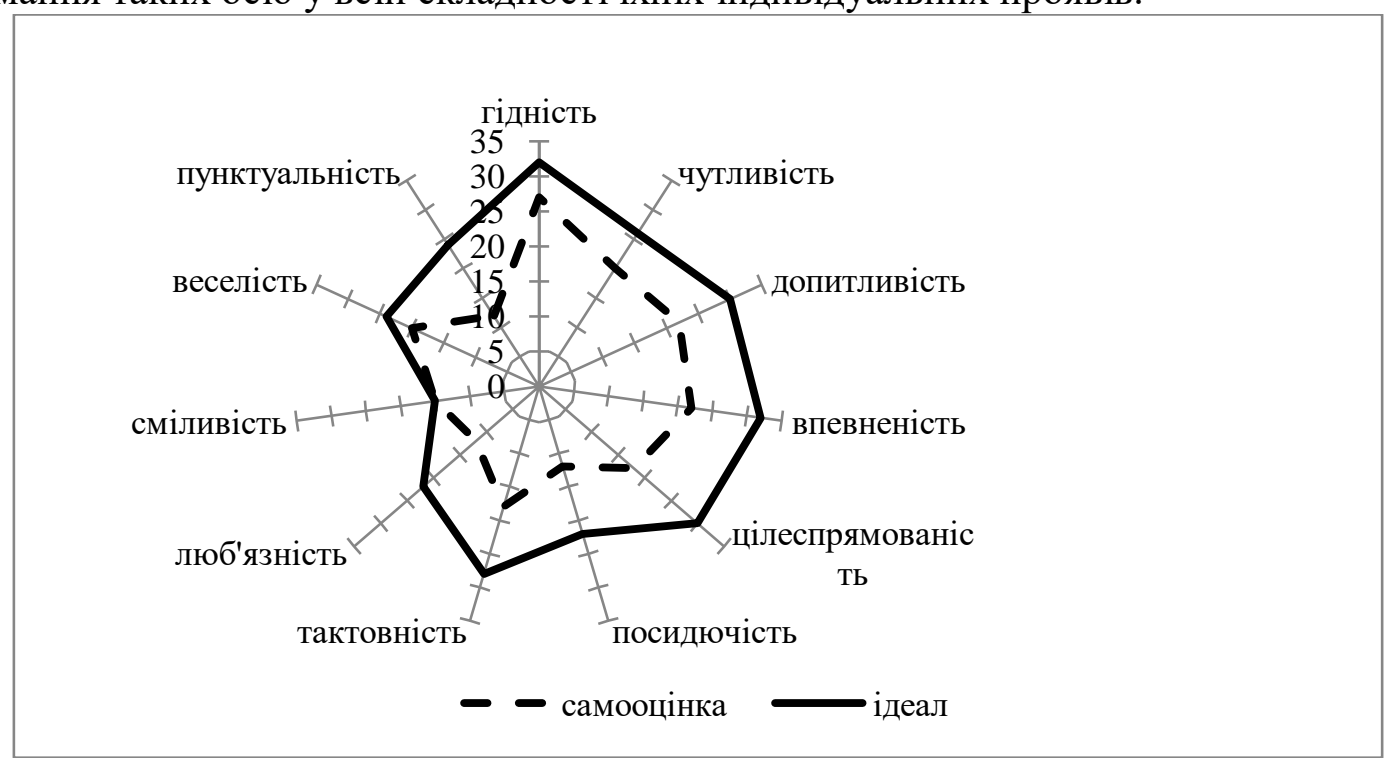

Рис. 5. Профіль самооцінювання студентів та оцінювання ними рис «ідеальної» особистості

Використання факторного аналізу сприяло виокремленню домінантних рис, які формують у студентів-психологів образ осіб з обмеженими можливостями. Схарактеризуємо їх відповідно до отриманих факторних навантажень. 
Перший фактор «Позитивні особистісні характеристики» пояснює 12,8\% дисперciї даних. На думку респондентів, позитивними якостями особистості осіб з інвалідністю $\epsilon$ допитливість, гідність, чутливість, веселість, пунктуальність. Індивідуальний досвід, елементи інклюзії в закладі вищої освіти, зміст освітньо-професійної програми, де представлені знання та необхідні компетентності для роботи з різними групами осіб, визначили сформованість уявлення про інвалідизовану особу та ії позитивні якості.

Другий фактор «Цілеспрямованість / наполегливість» пояснює 10,5\% дисперсії даних. Позитивні риси, які містить цей фактор, стосуються оцінювання здатності особистості долати труднощі, давати собі раду, вольові рис особистості інвалідизованого: впевнений, посидючий, сміливий, цілеспрямований. Розвиток цих якостей пов'язуємо 3 необхідністю подолання обмеження життєдіяльності завдяки набуттю впевненості в собі, здатності бути активним, енергійним, більш самостійним.

Третій фактор «Негативні особистісні характеристики» (інформативність 10,3\%). Його зміст представлений рисами, які описують негативні прояви осіб з обмеженими можливостями. Йдеться про боязливість, безхарактерність, безтурботність, байдужість. Однак вони, на думку респондентів, можуть бути подолані вольовим зусиллям. Окреслені якості типового інвалідизованого приписуються йому у зв'язку зі страхом перед спілкуванням 3 оточенням; домінуванням «медичної» моделі, яка превалює в суспільстві та визначає ставлення до цієї групи осіб як хворих, що потребують особливих умов життєдіяльності, постійного піклування, допомоги; деформованими рисами з огляду на тривале перебування в ускладнених ставленням умовах життя.

Четвертий фактор «Ставлення інвалідизованих до оточення» (інформативність фактора - 7\%). Цей фактор представлений двома полюсами якостей та властивостей. 3-поміж позитивних виокремлено тактовність, люб'язність, негативних - порушення психологічних кордонів. Прояв вказаних рис визначається, з одного боку, прагненням інвалідизованих до товариських стосунків, організації спільних дій, а з іншого - досвідом невизнання їх рівноправними членами товариства. В оточенні нерідко виникає страх щодо цієї групи осіб, боязнь виникнення у них прив'язаності, коли участь у житті інвалідизованого призведе до втрати власного особистого, соціального та часового психологічного простору.

Хоча проведене емпіричне дослідження засвідчило відсутність у сучасної молоді упередженого ставлення до осіб з інвалідністю та їх ізоляції від соціуму, водночас спричинилося до висновку, що попри високі показники когнітивного компонента ставлення молоді до інвалідів (усвідомлення актуальності цієї проблеми для суспільства, іiї прийняття та розуміння) їм притаманні зважені емоційні прояви (емпатія) та низький рівень конативного (поведінкового) складника, в якому попередні два знаходять своє втілення. Це визначило потребу розширення психологічної просвіти з метою надання об'єктивної інформації про соціальні, емоційні складники організації взаємин 3 інвалідизованими. Беззаперечно, факт використання інклюзивного підходу в закладах вищої освіти є значущою детермінантою зміни стереотипного уявлення про інвалідизованого у студентської молоді. Крім того, зазначимо, що спільне навчання та позанавчальна діяльність є оптимальним варіантом освітньої ситуації для усіх суб'єктів освітнього процесу.

Висновки. Ставлення в міжособистісному пізнанні вказують на той аспект взаємодії, який стосується зіставлення об'єктивного світу та його суб'єктивної інтерпретації. Зокрема, ставлення набуває вираженості з огляду на вияв потреби особистості співіснувати з різними об'єктами та суб'єктами середовища. Зміст психологічного ставлення формується під впливом соціальних настановлень, уявлень та індивідуального досвіду взаємодії з різними категоріями осіб.

Ставлення до людей 3 інвалідністю детерміновано сформованими суспільними (догми, ідеологеми чи ідеї інтеграції, інклюзії), політичними (державна політика, правове забезпечення) та культуральними (традиції, цінності, менталітет) чинниками. Їхня дія сприяє виникненню або прогресивних поглядів на місце інвалідизованого в соціумі, або, 
навпаки, деструктивно позначається на сприйманні його здатності бути повноцінним учасником суспільних змін. Означене пов'язують з проявом толерантного або інтолерантного ставлення до осіб з інвалідністю та актуалізації ролі освітнього середовища і психологічної просвіти в профілактиці гандикапізму.

Проведене емпіричне дослідження показало, що у студентської молоді сприймання інвалідизованих опосередковано домінуванням в сучасному суспільстві соціальної моделі інвалідності. Йдеться здебільшого про активно позитивне ставлення до спільного простору існування з особами з обмеженими можливостями, емпатії щодо них. Водночас констатовано, що такі результати є швидше соціальними уявленнями про власне ставлення, аніж результатом реального досвіду. Тому зроблено припущення про готовність студентів до адекватного сприймання осіб з інвалідністю та прояву ними позитивного ставлення до інвалідизованих. Підтвердженням цьому стали результати вивчення рівня толерантності студентської молоді. 3'ясовано переважання середніх показників. При цьому толерантність як особистісна риса виражена нижче, ніж її соціальний прояв. Толерування явищ, які спостерігаються в соціумі, є вищим внаслідок їх віддаленості, дистантності щодо респондента. Щодо внутрішньо особистісної детермінації, то вона ще потребує формування.

Особистісні риси психологічного портрета інвалідизованих, складеного студентами, засвідчили відсутність стереотипності уявлень, спрямованість на сприймання їх рівноправними учасниками життя та діяльності, здатними до оптимальної самореалізації. Водночас студенти закцентували на наявності індивідуальних варіантів психічної активності осіб з інвалідністю, а відповідно й ієрархії їхніх провідних рис.

Запропонований підхід до дослідження ставлення сучасної молоді до осіб з інвалідністю має свою специфічність, адже стосується соціального контексту співіснування різних категорій людей в єдиному хронотопі, що відкриває можливість інтегрувати результати дослідження в практику інклюзивної освіти в закладах вищої освіти, а також у соціально-психологічний аспект набуття молоддю відповідних соціальних компетентностей.

Перспективи дослідження вбачаємо в розширенні предметного пошуку та його спрямування на вивчення професійно зумовленого та статево-вікового аспектів формування психологічного ставлення до осіб з інвалідністю.

1. Аравіцька, М., Петрів, I. (2012). Соціально-психологічний моніторинг ставлення різних груп суспільства до осіб з особливими потребами. Вісник Прикарпатського університету. Фізична культура, 15, $151-157$.

1. Асмолов, А. (2001). Мы обречены на толерантность. Семья и школа, 11-12, 32-35.

2. Богучарова, О. (2013). Психологія ставлення до здоров'я: парадигми, моделі, чинники розвитку: автореф. дис. ... д-ра психол. н.: 19.00.01. Київ.

3. Демянюк, О. (ред.) (2008). Правовий захист осіб з функціональними обмеженнями: зб. нормативних документів (с. 14-20). Луцьк : Ред.-видав. центр ЛІРоЛ. 103-106.

4. Добровольская, Т., Шабалина, Н. (2002). Инвалиды: дискриминируемое меньшинство? Соиис, 5,

5. Домбровская, А. (2009). Формирование социальных стереотипов инвалидности. Вестник общественныхх наук, 2, 63-66.

6. Дубич, К. (2011). Ставлення суспільства до людей з обмеженими фізичними можливостями. Духовність особистості: методологія, теорія і практика, 3 (44), 30-35.

8. Кічук, А. (2006). Ціннісне ставлення як психологічний феномен. Психологія і суспільство, 3, 80-84.

7. Колупаєва, А. (2009). Іклюзивна освіта: реалії та перспективи. Київ : Самміт - Книга.

9. Курленкова, А. (2018). Инвалидность как эффект практик: попытка новой концептуализации. (Курленкова, А., Носенко-Штейн, В., отв. ред.) Обратная сторона Луны, или что мы не знаем об инвалидности: теория, репрезентации, практики (с. 25-42). Москва : ООО «Издательство МБА».

10. Мазай, Л. (2017). Соціально-психологічні стереотипи у ставленні до людей з інвалідністю. Молодий вчений, 3 (43), 271-274.

11. Обухівська, А. (2017). Психологічний супровід інклюзивної освіти : метод. рекомендації. Київ: УНМЦ практичної психології і соціальної роботи.

12. Пірог, Л. (2012). Сучасний стан інтеграції людей з обмеженими можливостями в суспільство. Вісник Дніпропетровського університету. Соціологія, 22, 135-140. 
14. Соціальна інклюзія в Україні: низький рівень прийняття найбільш вразливих дітей. URL : https://tsn.ua/ukrayina/socialna-inklyuziya-v-ukrayini-nizkiy-riven-priynyattya-naybilsh-vrazlivih-ditey542073.html.

8. Ставицький, О. (2013). Гандикапізм: психологічний аналіз. Рівне : Принт Хаус.

15. Ставицький, О. (2012). Ставлення до інвалідизованих у людей з різним рівнем освіти. Вісник Наџіонального університету оборони України, 4 (29), 256-262.

16. Nario-Redmond, M. R. (2010). Cultural stereotypes of disabled and non-disabled men and women: Consensus for global category representations and diagnostic domains. British journal of social psychology. Leicester, 3, 471-488.

\section{REFERENCES}

1. Aravitska, M., \& Petriv, I. (2012). Sotsialno-psykholohichnyi monitorynh stavlennia riznykh hrup suspilstva do osib z osoblyvymy potrebamy [Socio-psychological monitoring of the attitude of different groups of society to persons with special needs]. Visnyk Prykarpatskoho universytetu. Fizychna kultura. 15, 151-157. (ukr.).

2. Asmolov, A. (2001). My obrecheny na tolerantnost [We are doomed to tolerance]. Semya i shkola. 11-12, 3235. (rus.).

3. Bohucharova, O. (2013). Psykholohiia stavlennia do zdorovia: paradyhmy, modeli, chynnyky rozvytku [Health psychology: paradigms, models, factors of development]. Extended abstract of Doctor's thesis (Psychol. Sci.: 19.00.01). Kyiv. (ukr.).

4. Demianiuk, O. (Ed.) (2008). Pravovyi zakhyst osib z funktsionalnymy obmezhenniamy [Legal protection of persons with functional limitations] (pp. 14-20). Lutsk: Red.-vydav. tsentr LIRoL. (ukr.).

5. Dobrovolskaya, T., \& Shabalina, N. (2002). Invalidy: diskriminiruemoe menshinstvo? [Persons with disabilities: a discriminated minority?] Socis. 5, 103-106. (rus.).

6. Dombrovskaya, A. (2009). Formirovanie socialnyh stereotipov invalidnosti [The formation of social stereotypes of disability]. Vestnik obshestvennyh nauk. 2, 63-66. (rus.).

7. Dubych, K. (2011). Stavlennia suspilstva do liudei z obmezhenymy fizychnymy mozhlyvostiamy. [Attitudes of society towards people with disabilities]. Dukhovnist osobystosti: metodolohiia, teoriia i praktyka. 3 (44), $30-35$. (ukr.).

8. Kichuk, A. (2006). Tsinnisne stavlennia yak psykholohichnyi fenomen [Value attitude as a psychological phenomenon]. Psykholohiia i suspilstvo. 3, 80-84. (ukr.).

9. Kolupaieva, A. (2009). Ikliuzyvna osvita: realii ta perspektyvy [Inclusive education: realities and perspectives]. Kyiv: Sammit - Knyha. (ukr.).

10. Kurlenkova, A. (2018). Invalidnost kak effekt praktik: popytka novoj konceptualizacii [Disability as an effect of practices: an attempt at a new conceptualization]. (A. Kurlenkova, V. Nosenko-Shtejn, Eds.). Obratnaya storona Luny, ili chto my ne znaem ob invalidnosti: teoriya, reprezentacii, praktiki - The flip side of the moon, or what we don't know about disability: theory, representations, practices (pp. 25-42). Moskva: OOO «Izdatelstvo MBA». (rus.).

11. Mazai, L. (2017). Sotsialno-psykholohichni stereotypy u stavlenni do liudei z invalidnistiu [Sociopsychological stereotypes towards people with disabilities]. Molodyi vchenyi. 3 (43), 271-274. (ukr.).

12. Obukhivska, A. (Ed.) (2017). Psykholohichnyi suprovid inkliuzyvnoi osvity [Psychological support of inclusive education]. Kyiv: UNMTs praktychnoi psykholohii i sotsialnoi roboty. (ukr.).

13. Piroh, L. (2012). Suchasnyi stan intehratsii liudei z obmezhenymy mozhlyvostiamy v suspilstvo [Current state of integration of people with disabilities into society]. Visnyk Dnipropetrovskoho universytetu. Sotsiolohiia. 22, 135-140. (ukr.).

14. Sotsyalna inkliuziia v Ukraini: nyzkyi riven pryiniattia naibilsh vrazlyvykh ditei [Social inclusion in Ukraine: Low acceptance of most vulnerable children]. Retrieved from https://tsn.ua/ukrayina/socialna-inklyuziyav-ukrayini-nizkiy-riven-priynyattya-naybilsh-vrazlivih-ditey-542073.html. (ukr.).

15. Stavytskyi, O. (2013). Handykapizm: psykholohichnyi analiz [Handicapism: A psychological analysis]. Rivne: Prynt Khaus. (ukr.).

16. Stavytskyi, O. (2012). Stavlennia do invalidyzovanykh u liudei z riznym rivnem osvity [Attitudes towards people with disabilities in persons of different educational backgrounds]. Visnyk Natsionalnoho universytetu oborony Ukrainy. 4 (29), 256-262. (ukr.).

17. Nario-Redmond, M. R. (2010). Cultural stereotypes of disabled and non-disabled men and women: Consensus for global category representations and diagnostic domains. British journal of social psychology. Leicester, 3, 471-488.

\section{Olena Halian, Ihor Halian PERSONALITY WITH DISABILITIES IN REFLECTIONS OF STUDENTS-PSYCHOLOGISTS}

Theoretical and applied aspects of the formation of cognitive, emotional and connactive components of students attitudes towards persons with disabilities (disabled) are analysed in this article. Interpersonal cognition reflects of the aspect that comparison of the objective world and its subjective interpretation. Psychological attitude content is formed under the social setting, representations and individual experience of interaction with different 
categories of persons. The dominance of the social model of persons with disabilities perception, in which the leading role belongs to finding a place for people with disabilities in society, determining the ways of its selfrealization and optimal realization own life, is demonstrated. In modern society there is tendency to replace perception stereotypes of persons with disabilities professional representations, which outline approaches to the formation of a tolerant attitude towards this people group in society. It is indicated on the influence social and personality context of students' tolerance on the attitude to persons with disabilities. The factors that determine the perceptions and attitudes to people with disabilities are specified. Emphasis on personal, volitional and sociopsychological manifestations of persons with disabilities is recognized as determinants of the formation of a system of attitudes towards this group of people in students. At the same time, students are focused on the availability of individual options for psychological activity of people with special needs, and, accordingly, the hierarchy of leading rice. This determined the need to improve the psychological and pedagogical support of the personal development of students in the university, where are supports the desire of all subjects of the educational process to productive self-realization.

Keywords: psychological attitude, components of attitude, models of perception of persons with disabilities, disabled person, psychological portrait of the disabled, tolerance, self-realization. 